\title{
Boring sponges and the modeling of coral reefs in the east Pacific Ocean
}

\author{
José Luis Carballo $^{1, *}$, Eric Bautista-Guerrero ${ }^{1}$, Gerardo E. Leyte-Morales ${ }^{2}$ \\ ${ }^{1}$ Instituto de Ciencias del Mar y Limnología, UNAM (Estación Mazatlán), Apartado postal 811, 82000 Mazatlán, México \\ ${ }^{2}$ Universidad del Mar, Campus Puerto Ángel, Oaxaca, Apartado postal 47, Puerto Ángel, 70902 Oaxaca, México
}

\begin{abstract}
A total of 900 coral fragments collected across 2 fringing reefs located southwest of Mexico, La Entrega (LE) and San Agustín (SA), were examined for the presence of boring sponges. Of all samples, $43 \%$ were invaded by boring sponges, and 7 species belonging to 5 genera ( $A k a$, Cliona, Pione, Cliothosa and Thoosa) were identified. The most abundant species were Cliona vermifera $(17.9 \%)$, Cliona sp. $(10.8 \%)$, A. cryptica $(7.8 \%)$ and P. carpenteri $(6.0 \%)$. The distribution and abundance of the species varied considerably throughout the reef area (margin and platform) and displayed certain selectivity for specific calcareous substrata. C. vermifera, Cliona sp., A. cryptica and $P$. carpenteri were most common on the reef margins, while T. calpulli was common on the central platform. A. cryptica, P. carpenteri, and Cliothosa hancocki were frequently found living in the immediate vicinity of live coral tissue, contrary to C. vermifera, T. calpulli and Cliona mucronata, which preferentially bored coral rubble. The results showed that reef margins had a significantly higher infestation level than the platforms (mean infestations of 60.6 and $26.2 \%$, respectively). There were also differences between reefs. The infestation was higher on LE than on SA (48.6 and $38.2 \%$, respectively), and these differences were larger between the platforms of the 2 reefs ( 41.3 and $11.1 \%$, respectively). In general, the results of the present study have demonstrated that the diversity and abundance of species, as well as the infestation of coral frameworks by sponges, was significantly higher in the margin at both reefs studied and on the platform of LE, where the availability of exposed carbonate substrate was higher. In the margin of these reefs, the consequences of boring went far beyond the mere hollowing out of a few cavities, since by weakening the coral's attachment to the substrate, the sponges accelerated coral loss and restructured the reef edge. This pattern may have important implications for the preservation of the reef framework.
\end{abstract}

KEY WORDS: Bioerosion • Boring sponges · Fringing coral reefs · Reef margin • Reef flat • Mexican Pacific

\section{INTRODUCTION}

Coral reefs are diverse and productive biological communities that form massive biogenic structures and serve as a refuge for a multitude of sessile and mobile organisms (Richmond 1993). In the Atlantic and Indo-Pacific Oceans, coral reefs show typical zonation patterns (lagoon, back-reef and fore-reef) (Stoddart 1973). In contrast, in the East Pacific Ocean the reef framework is narrow and does not form a crest or a lagoon between the crest and the shoreline (Carriquiry \& Reyes-Bonilla 1997, Reyes-Bonilla 2003). This general structure, constructed mainly by coral of the genus
Pocillopora, can be frequently observed from the Gulf of California to Central America (Glynn \& LeyteMorales 1997, Glynn \& Ault 2000, Reyes-Bonilla 2003). In this region, some studies have examined reef growth (Cortés et al. 1994) and the effects on their structure from climatic events like the El Niño Southern Oscillation (ENSO) (Reyes-Bonilla et al. 2002), but there are very few data on the destruction and bioerosion of these reefs (Londoño-Cruz et al. 2003).

Bioerosion is an essential, and often overlooked, aspect of reef ecology, and it is perhaps the most important destructive force on coral reefs (Zubia \& Peyrot-Clausade 2001). Bioeroding species of many 

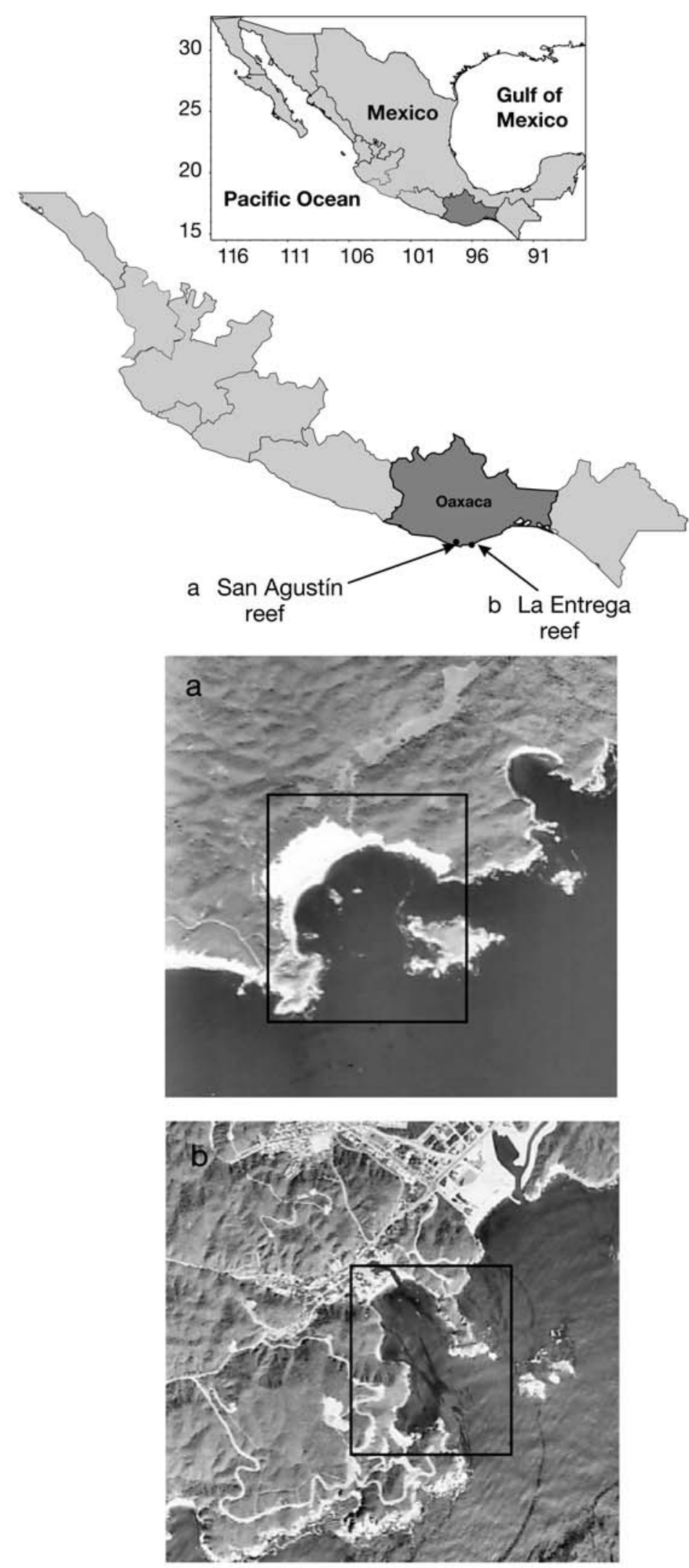

Fig. 1. Reef locations: (a) San Agustín and (b) La Entrega different types of organisms, which act on the environment in a wide variety of ways, interact with the ecosystem and with each other as part of the cycle of reef growth and degradation (Macdonald \& Perry 2003). Amongst these, the boring sponges are considered one of the main agents that modify coral reef ecosystems (Goreau \& Hartman 1963, MacGeachy 1977). Globally, they are the most common type of macroendolith and are responsible for more internal degradation of coral than any other group of organisms, internally (Perry 1998). They can accelerate the erosion of the reef framework (Tunnicliffe 1979) and cause a shift in the carbonate balance (Rose \& Risk 1985). Sponges obviously play one of the most important roles in bioerosion worldwide. However, they have been omitted in most studies because of their complex taxonomy and cryptic habitat that makes their quantification difficult (Schönberg 2001a,b).

In the Mexican Pacific Ocean most studies have focused on the taxonomic description of sponge species living in coral and other carbonate substrates (Carballo et al. 2004, 2007). Thus, there are very few data on the spatial distribution, diversity, abundance and effects that these sponges have on the reef framework.

The present study assesses the composition of boring sponge species, their abundance, substrata preference and the degree of framework infestation across 2 fringing coral reefs in the Mexican Pacific Ocean. One interesting feature of these fringing-reef corals is that 2 contrasting zones can be identified: (1) the margin or reef edge, with a higher quantity of exposed carbonate substrate, and (2) the central platform or reef flat, where live coral colonies form a more compact structure, increasing live surface area and decreasing the area of exposed carbonate substrate. We tested the hypothesis that abundance and diversity of boring sponges will be higher on the margin than on the central platform.

\section{MATERIALS AND METHODS}

Study location. The Huatulco reefs (Huatulco bays, Oaxaca, southwestern Mexico, Fig. 1) are fringing reefs constructed predominantly by branching pocilloporid corals (Glynn \& Leyte-Morales 1997), but some massive species of the genus Porites and Pavona also occur (Reyes-Bonilla 2003). These coral reefs are located in bays, and usually extend down to $14 \mathrm{~m}$. This research was conducted on La Entrega (LE) and San Agustín (SA) reefs (7.3 and 2.5 ha respectively), which were chosen because of their similar frameworks. Both reefs are constructed by interlocking branches of species of the genus Pocillopora that stabilize a continuous 
platform (Fig. 2b), surrounded by wide zones of exposed carbonate substrate that form the borders of the reef (1 to $3 \mathrm{~m}$ wide) (Fig. 2a). Sandy bottoms, with patches of coral fragments and calcareous algae, surround the framework of both reefs, and their general structure corresponds to that normally observed on coral reefs in the east-central Pacific (Carriquiry \& Reyes-Bonilla 1997, Reyes-Bonilla 2003). Glynn \& Leyte-Morales (1997) give more detailed information on these reefs including bathymetry, cover and conservation.

Characterization of the reef environment. A set of environmental variables was measured on the reef flat of both reefs, including suspended particulate matter (SPM) concentration, chlorophyll a ( $\mathrm{chl} \mathrm{a}$ ) concentration, water transparency, sediment deposition, water movement and water temperature. The data were collected twice, during the wet season (July) and the dry season (April). SPM was calculated by filtering 31 of seawater, with the filter subsequently oven-dried and weighed. Chlorophyll sampling and analysis followed the methods described by Holm-Hansen (1978). Irradiance ( $\mu$ mol quanta $\mathrm{m}^{2} \mathrm{~s}^{2}$ ) was evaluated using a LICOR data logger at $1 \mathrm{~m}$ intervals to a depth of $5 \mathrm{~m}$. Irradiance was used to calculate the attenuation coefficient (kd). Water transparency was estimated horizontally with a Secchi disc. Sediment deposition was measured using a trap system, consisting of 2 sets of cylindrical plastic bottles (1 1), positioned with their mouths $(2.9 \mathrm{~cm}$ in diameter) at $60 \mathrm{~cm}$ above the reef platform. Each bottle was held in position in a vertical PVC cylindrical tube that was attached to the bottom for $1 \mathrm{wk}$ each sampled season. The collected material was rinsed with distilled water to remove salts and dried at $60^{\circ} \mathrm{C}$ for $24 \mathrm{~h}$ before weighing. To estimate the water movement, we used the 'plaster dissolution' method, consisting of 2 sets of plaster spheres $5 \mathrm{~cm}$ in diameter (Naranjo et al. 1996). Deployment and retrieval of the plaster spheres were done every $3 \mathrm{~d}$ during each sampling period (10 d). The effect of water temperature on dissolution rates of the plaster spheres was corrected through a regression model previously calculated in the laboratory. Water temperature was measured daily during every sampling period with a HOBO water temperature data logger placed at a depth of $6 \mathrm{~m}$.

Quantification of boring sponge infestation frequency. Branches of coral colonies (Pocillopora damicornis) of 3 different categories were collected by SCUBA diving in April 2004. The classification of the coral colonies was based on a modification of the methodology described by Peyrot-Clausade et al. (1992): (1) live coral colonies of $P$. damicornis attached to the substrate (Fig. 2c), (2) colonies partially alive and

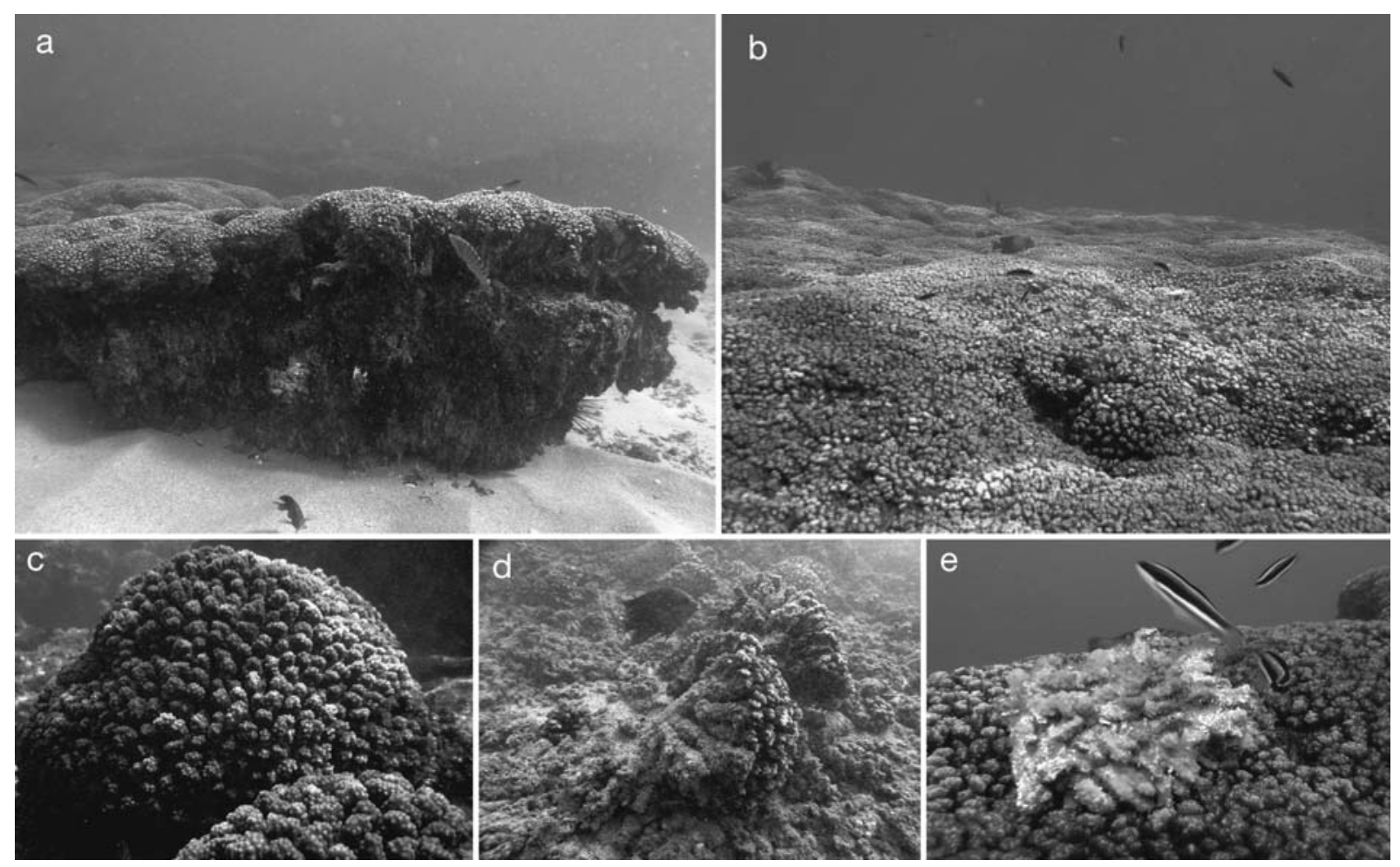

Fig. 2. San Agustín reef: (a) margin, (b) central platform, and classification substrata used in the present study: (c) attached live coral colony, (d) detached live coral colony, (e) coral rubble 
detached from the substrate (Fig. 2d), and (3) fragments of dead coral commonly called 'rubble' (Fig. 2e).

On each reef, 3 line transects $50 \mathrm{~m}$ long were run along the central platform, and 3 more transects were run around the margin of the reef edge. Along each transect, a complete branch (Category 1 and 2) and rubble (Category 3) were collected at random every $2 \mathrm{~m}$ ( 25 samples for each category), yielding 75 samples per transect. For Category 1 a complete branch (from the tip to the stem) was collected from the colony closest to the transect. Thus, a total of 225 branches were collected from the central platform and 225 from the margin in each reef (450 branches per reef).

In the laboratory the coral branches were cut into parallel slices at right angles to the axis and examined for the presence of boring sponges. Identification of boring sponges was based mainly on Carballo et al. (2004) and Carballo et al. (2007). Spicule preparation followed the techniques described by Rützler (1974) for light and scanning electron microscopy (SEM). The material has been deposited in the Colección de Esponjas del Pacífico (LEB-ICML-UNAM) of the Instituto de Ciencias del Mar y Limnología, UNAM, in Mazatlán, México.

The occurrence/non-occurrence of boring sponges in each sample collected was expressed as percentage of infestation per category $(1,2,3)$, per reef zone (central platform and margin), and per reef (LE and SA). The average of the 6 transects on each reef ( 3 from the central platform and 3 from the margin) was used to determine the total percentage of infestation by boring sponges per reef.

Data analysis. Using the environmental parameters, a correlation-based principal components analysis (PCA) was applied to characterize the environment of both reefs. A series of 2-way ANOVAs were carried out separately to study the variation of environmental variables between seasons and reefs. Where necessary, data were log transformed.

The percentage of infestation was compared between reefs using a 3-way ANOVA with the factors Locality (2 levels), Zone (2 levels) and Coral Colony Category (3 levels). Separate means of Coral Colony Category were compared using the Student-Newman-Keuls (SNK) post hoc test (Zar 1984) to determine which of the means were significantly different. The statistical package STATISTIC v. 7.1 was used for ANOVA analyses.

\section{RESULTS}

\section{Reef environment}

The ordination of environmental factors of the reefs by PCA (Fig. 3, cumulative percent variation explained

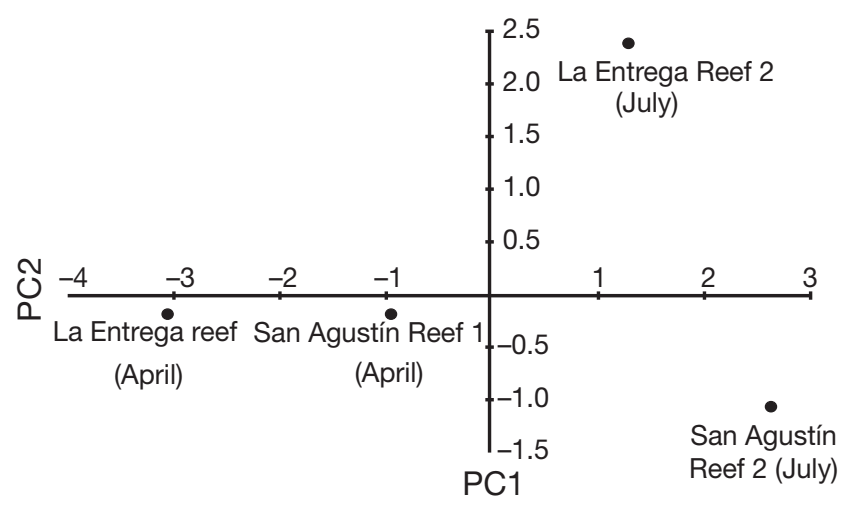

Fig. 3. Principal components analysis (PCA) ordination of coral reefs based on environmental parameters (as listed in 'Materials and methods')

$83.2 \%)$ showed a difference between the wet and dry seasons, irrespective of the reef (temporal variation, first principal component [PC1], $61.3 \%$ of the total variance explained). Chl a concentration, phosphate and total $\mathrm{N}$ were higher in April, the dry season $(\mathrm{p}<$ $0.0001, p=0.0212$ and $p=0.0002$, respectively, separate 2-way ANOVAs), while water transparency and suspended solids in the water column had higher values in July, the wet season ( $p=0.0002$ and $p=0.0179$, respectively, separate 2 -way ANOVAs). The second principle component (PC2) (spatial variation, $21.9 \%$ of variation explained) showed that there were also differences between the reefs themselves, largely independent of the sampling season. LE was richer in organic matter and had a higher chl a concentration and sedimentation rate $(\mathrm{p}=0.0235, \mathrm{p}<0.0001$ and $\mathrm{p}<$ 0.0001 , respectively, separate 2-way ANOVAs), with sedimentation rates at $340 \mathrm{~g} / \mathrm{m}^{-2} \mathrm{~d}^{-1}$ for April and $199 \mathrm{~g} / \mathrm{m}^{-2} \mathrm{~d}^{-1}$ for July, respectively. In contrast, water movement was significantly higher at SA $(p<0.0001$, separate 2-way ANOVA). There were no significant differences in water temperature or irradiance between localities and seasons.

\section{Boring sponge species richness}

Nine hundred coral branches from LE and SA were collected and analyzed. Boring sponges invaded $43 \%$, and 7 species belonging to 5 genera were identified (Cliona, Pione, Cliothosa, Aka, and Thoosa). Of the 7 species identified, 5 were found on LE: Cliona vermifera, Cliona sp., P. carpenteri, A. cryptica and T. calpulli, and 7 in SA: C. vermifera, Cliona mucronata, Cliona sp., P. carpenteri, A. cryptica, T. calpulli and Cliothosa hancocki. The most abundant species were C. vermifera $(17.9 \%$ of all samples), Cliona sp. 
$(10.8 \%)$, A. cryptica $(7.8 \%)$ and P. carpenteri $(6.0 \%)$. C. hancocki and C. mucronata were uncommon at the sample sites.

Cliona sp., the second most common sponge, is an undescribed species, and a brief diagnosis is necessary to make its identification easy. This is a bright yellow sponge in alpha form, i.e. superficially showing only circular or oval-shaped papillae 0.5 to $1.9 \mathrm{~mm}$ in diameter (4 to 8 papillae $\mathrm{cm}^{-2}$ ). The tylostyles are slender, with the shaft slightly bent in the upper third, with a mean length and width of 193.4 and $5 \mu \mathrm{m}$, respectively $(\mathrm{N}=50)$. The spirasters are straight, slightly curved or spiral-shaped, with 2 to 5 turns (mean length $25 \mu \mathrm{m}$, $\mathrm{N}=50$ ), and possess very fine short thorns generally terminating in branches.

\section{Spatial patterns of boring sponge occurrence}

Considering all samples, sponge infestation differed significantly between reefs (Table 1): $38.2 \%$ of the fragments were affected at SA versus $48.6 \%$ at LE (Fig. 4). This difference was more pronounced when comparing only the platforms of the 2 reefs (11.1 and $41.3 \%$, respectively, Fig. 4). Regardless of the respective reef, sponges were more common on the margins than on the platforms (Fig. 4).

On LE all 5 species found occurred both on the reef margin and on the central platform, except for Aka cryptica, which was exclusively found on the margin. Cliona vermifera (69.3\%), Cliona sp. (64\%) and Pione carpenteri $(32 \%)$ were the most abundant species on the margin (Fig. 5a). This same pattern of dominance was observed on the central platform, although the frequency for each species was lower; 51,47 and $21 \%$, respectively (Fig. 5b).

Aka cryptica was found exclusively in branches of detached live colonies, but the rest of the species did

Table 1. ANOVA comparing the frequency of infestation in the reefs of La Entrega and San Agustín. Factors: locality (2 levels: La Entrega and San Agustín), zone (2 levels: margin and central platform) and coral colony category (3 levels: 1,2 and 3$).{ }^{*}$ Significant $(\mathrm{p}<0.05)$

\begin{tabular}{|lrrrc|}
\hline Factor & df & MS & $F$ & $\mathrm{p}$ \\
\hline Frequency of infestation & & & & \\
Locality & 1 & 61.36 & 11.32 & $0.0026^{*}$ \\
Zone & 1 & 667.36 & 123.20 & $<0.0001^{*}$ \\
Colony category & 2 & 6.02 & 1.11 & 0.3450 \\
Locality $\times$ Zone & 1 & 220.02 & 40.62 & $<0.0001^{*}$ \\
Locality $\times$ Colony category & 2 & 0.52 & 0.09 & 0.9075 \\
Zone $\times$ Colony category & 2 & 35.02 & 6.46 & $0.0056^{*}$ \\
Locality $\times$ Col. cat. $\times$ Zone & 2 & 20.19 & 3.73 & $0.0389^{*}$ \\
Residual & 24 & 5.41 & & \\
\hline
\end{tabular}

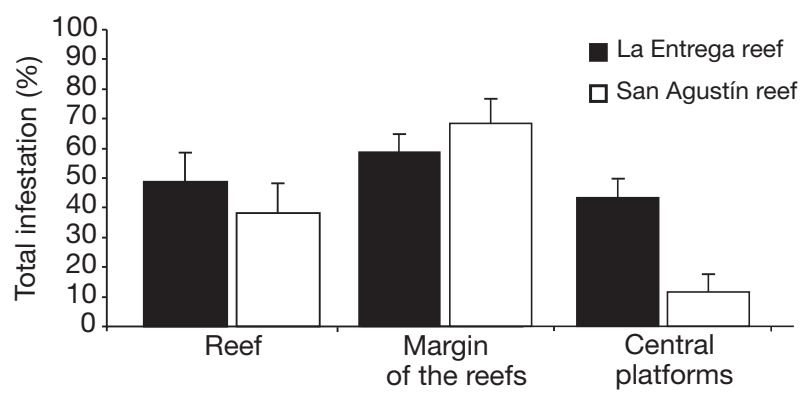

Fig. 4. Percentage of boring sponge infestation by reef and reef zone $(+\mathrm{SD})$

not show a clear specificity for any of the coral colony categories. However, Cliona vermifera occurred mainly in coral rubble, while Cliona sp. was more common in branches of attached and detached live colonies (Fig. 5d).

Sponge infestation of all substrate categories together was significantly higher on the margin (56\%) than on the central platform of LE (41.3\%) (Fig. 4). However, this pattern was not consistent when considering the categories separately, since rubble was more infested on the central platform $(58.6 \%)$ that on the margin (46.6\%) (Fig. 5c). Infestation was higher in the rubble $(53 \%)$, followed by detached and attached live coral (both $47 \%$ ) (Fig. 5d).

Species were evenly distributed among the zones on SA, except for Cliothosa hancocki and Cliona mucronata, which were exclusively found on the margin. The most abundant species on the margin were Aka cryptica $(81 \%)$ and Cliona vermifera $(77 \%$, Fig. $6 a)$. On the central platform this pattern was the same, but the frequency of all species was lower, with $C$. vermifera found in $17 \%$ of all fragments (Fig. 6b). In this reef some species, such as A. cryptica (19.3\%) and Pione carpenteri $(4.7 \%)$, were frequently found in branches of unattached live coral; Cliona sp. was found in branches of attached live coral (6.7\%). In contrast, $C$. vermifera was more frequent in coral rubble $(27.7 \%)$. The frequency of infestation was similar in the 3 categories considered: $40 \%$ in rubble (Coral category 3 ), $38 \%$ in attached coral (Category 1) and $36 \%$ in detached live coral colonies (Category 2) (Fig. 6d). As at $L E$, the sponge infestation was significantly higher on the margin $(65.3 \%)$ than on the central platform (11.1\%, Fig. 4, Fig. 6c).

Abundances and distribution patterns of all the species are summarised in Table 2. Cliona vermifera, Cliona sp., Aka cryptica and Pione carpenteri were most commonly found on the reef margins, and only Thoosa calpulli was observed to occur commonly on the central platforms. Cliothosa hancocki and Cliona mucronata were found only on the reef margins. 


\section{Substrate effects on sponge infestation}

Regardless of reef origin, no significant difference was found in sponge infestation of the 3 coral colony categories representing substrate attributes (Table 1). Including samples from both reefs, the average value of infestation was $46.6 \%$ in rubble (Coral Category 3 ), $42.3 \%$ in attached live coral (Category 1 ) and $41.3 \%$ in
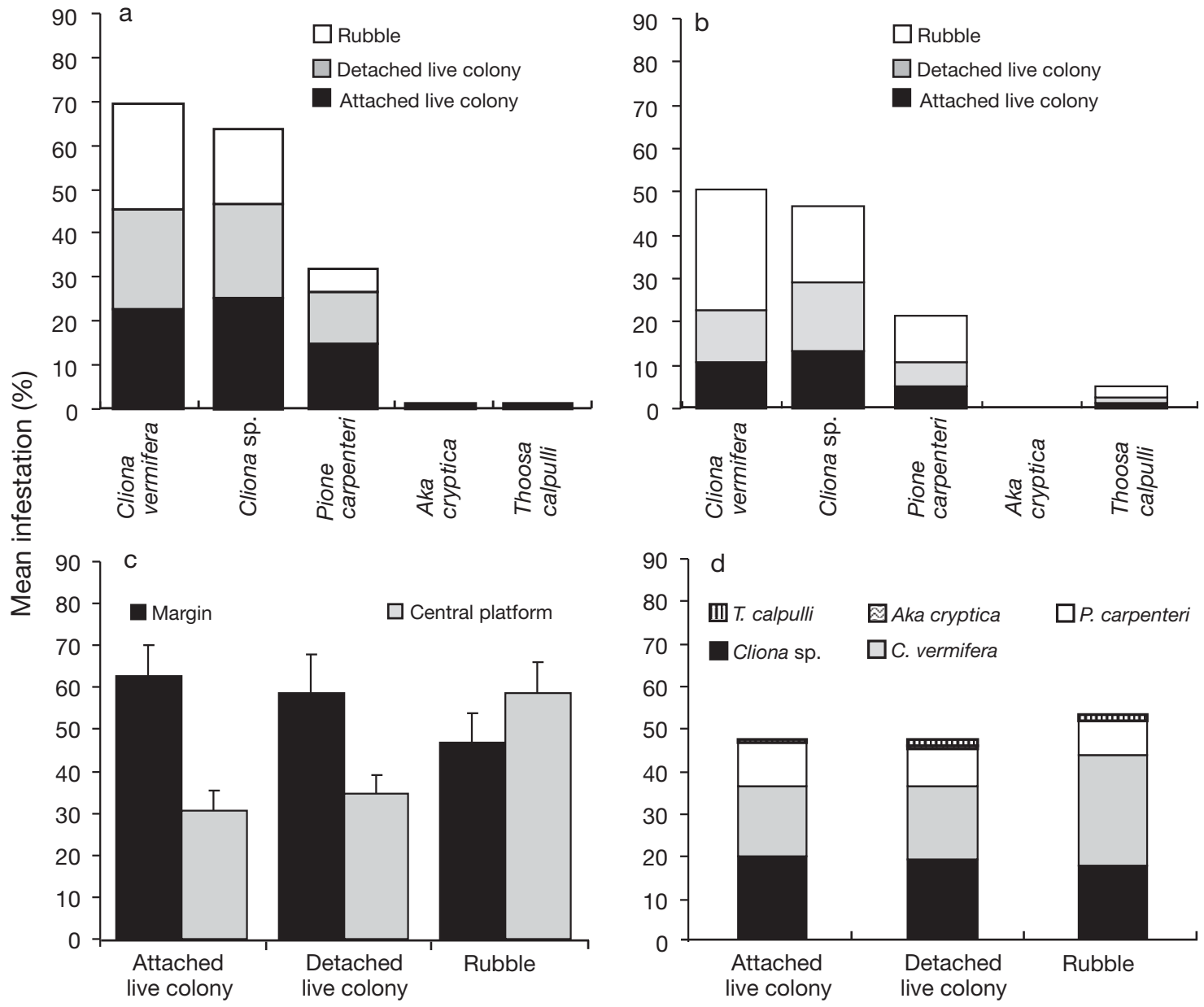

Fig. 5. Boring sponge infestation at La Entrega (LE) reef. Mean percentage of infestation by species (a) in the margin and (b) in the central platform, and by substrata category. (c) Comparison of the percentage of infestation between the margin and central platform. (d) Percentage of infestation by substrata category

Table 2. Number of samples collected $(\mathrm{N})$ and number of these invaded $\left(\mathrm{N}_{\text {inv }}\right)$, percentage of infestation and relative abundance of boring sponge species by reef zone and coral colony category. The abundance of boring sponges was estimated from the number of samples invaded. CP: central platform; AL: attached live; DL: detached live; Cv: Cliona vermifera; Csp: Cliona sp.; Ac: Aka cryptica; PC: Pione carpenteri; TC: Thoosa calpulli; Ch: Cliothosa hancocki; Cm: Cliona mucronata

\begin{tabular}{|c|c|c|c|c|c|c|c|c|c|c|}
\hline & \multirow[t]{2}{*}{$\mathrm{N}$} & \multirow[t]{2}{*}{$\mathrm{N}_{\text {inv }}$} & \multirow{2}{*}{$\begin{array}{c}\text { Mean } \\
\text { infestation (\%) }\end{array}$} & \multicolumn{7}{|c|}{ Relative abundance } \\
\hline & & & & $C V$ & Csp & $A C$ & $P_{C}$ & $T C$ & $\mathrm{Ch}$ & $\mathrm{Cm}$ \\
\hline \multicolumn{11}{|c|}{ Reef zones } \\
\hline Margin & 450 & 273 & 60.6 & 68.3 & 61.9 & 88.6 & 68.5 & 28.6 & 100 & 100 \\
\hline $\mathrm{CP}$ & 450 & 118 & 26.2 & 31.3 & 38.1 & 11.4 & 31.5 & 71.4 & 0.0 & 0.0 \\
\hline \multicolumn{11}{|c|}{ Colony category } \\
\hline $\mathrm{AL}$ & 300 & 127 & 42.3 & 26.1 & 33.0 & 41.4 & 40.7 & 14.3 & 100 & 0.0 \\
\hline DL & 300 & 124 & 41.3 & 24.8 & 39.2 & 37.1 & 33.3 & 28.6 & 0.0 & 0.0 \\
\hline Rubble & 300 & 140 & 46.6 & 49.1 & 27.8 & 21.4 & 25.9 & 57.1 & 0.0 & 100 \\
\hline
\end{tabular}



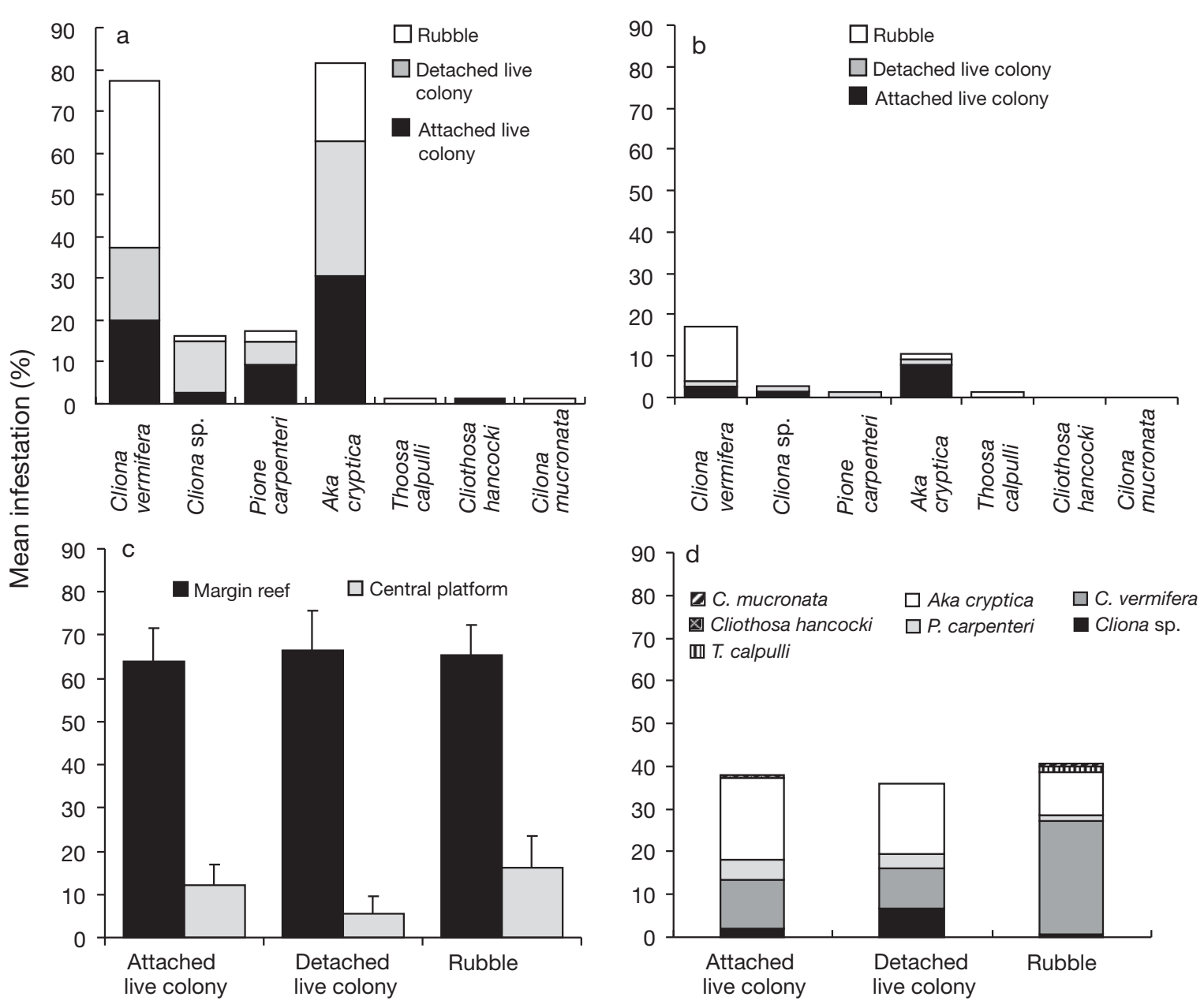

Fig. 6. Boring sponge infestation at San Agustín (SA) reef. Mean percentage of infestation by species (a) in the margin and (b) in the central platform, and by substrata category. (c) Comparison of the percentage of infestation between the margin and central platform. (d) Percentage of infestation by substrata category

detached live coral (Category 2) (Table 2). However, the significant interaction between zone and colony category showed that infestation per category could vary between reef zones. On the central platform of the reefs, rubble was more infected than the other 2 categories, with $37.3 \%$ in rubble versus $21 \%$ in attached coral and $20 \%$ in detached live coral.

Sponge species did not show a strict preference for any of the coral colony categories. Cliona sp. was common in the 3 coral categories, but more common in branches of attached and detached live colonies than in rubble (Table 2), while Cliona vermifera occurred mainly in coral rubble and less frequently in attached and detached live coral colonies. Cliona sp., Aka cryptica and Pione carpenteri were mostly found invading the dead parts of both detached and attached live colonies, but also inhabited a small quantity of rubble (Table 2). In contrast, Thoosa calpulli mainly invaded rubble and was less common in attached and detached live coral colonies. Cliothosa hancocki only occupied dead parts of attached live coral colonies, whereas the few specimens of Cliona mucronata found during the present study occurred exclusively in rubble (Table 2).

\section{DISCUSSION}

In recent years, boring sponges have been profusely studied on the Mexican Pacific coast, although most of these studies have focused on taxonomic descriptions (Carballo et al. 2004, 2007). Thus, the present study is the first to provide data about distribution, abundance, infestation and substrate preferences of boring sponges on 2 different coral reefs from the Pacific coast of Mexico.

The number of boring sponges found on the Huatulco reefs is comparable to that registered for other coral-dominated areas. For example, at Orpheus 
Island, Great Central Great Barrier Reef, Australia, Schönberg (2001a) distinguished more than 8 different species of boring sponges, and at Discovery Bay (Jamaica), Perry (1998) reported a dominance of boring sponges in the fore-reef, with a total of 10 species. Other authors like Buznego \& Alcolado (1987) reported 12 species of boring sponges in scleractinian corals in the southern and northwest regions of Cuba.

One of the most important results of the present study was that the highest sponge infestation was registered on the margins of both reefs $(60.6 \%$ vs. $26.2 \%$ on the central platform). We attributed this difference to the extensive areas of exposed carbonate substrate on the reef margins, which is easily colonized by boring sponges. Substrate availability for larval settlement is one of the most important factors that control the establishment, distribution and abundance of boring sponges (Kiene \& Hutchings 1994, Schönberg 2001a, Schönberg \& Wilkinson 2001). The present results highlight the marked effect of the availability of calcareous substrata free of live coral on boring sponge occurrence.

In the Caribbean reefs the effects of sponge boring are also most obvious on deep slopes, where the density of living coral is already low and large areas of bare substrate are available for sponge larval settlement (Goreau \& Hartman 1963). However, zonedependent occurrence may also be related to the different levels of environmental factors to which habitats are subjected, such as wave energy and sedimentation (Macdonald \& Perry 2003). Intense sedimentation incurs the risk of burial and is an important factor influencing distribution patterns of boring sponges. Species of the genus Aka are well adapted to survive burial and are common in shallow depths and in sandy bays (Rützler 1971). The present study showed that Aka cryptica was very abundant on SA, where we registered the highest rate of sedimentation (340 $\left.\mathrm{g} \mathrm{m}^{-2} \mathrm{~d}^{-1}\right)$. At Barbados, rubble collected from the back reef contained significantly fewer clionaid sponges than rubble collected from other reef zones (Holmes 2000). The constant wave action, scour, high sedimentation and occasional burial made this zone comparatively inhospitable to boring sponges. In contrast, the subtidal part of the reef margin usually represents an advantageous habitat for bioeroding sponges due to the low risk of extreme temperatures, exposure and desiccation, such as on the reef flat (Schönberg 2001a), good water circulation and comparatively high concentrations of nutrients (e.g. Wild et al. 2005).

We also found distribution patterns related to the occupied substrata that may also be related to survival abilities and competitive advantages. For example, while Cliothosa hancocki can exist at a relatively close distance to live coral tissue, Cliona mucronata was only found in dead pieces of rubble. Some species of Cliona are able to live in the immediate vicinity of live coral tissue but kill it (e.g. Schönberg \& Wilkinson 2001) with the production of toxic mucus (Rützler 1971). The availability of dead substrate per reef or zone will affect spatial distribution patterns.

The presence of bioeroders has been considered a key factor that contributes to the weakening of reef framework (Glynn \& Colgan 1992). The pattern reported in the present study may have important implications for the preservation of the reef framework, since it suggests that the destruction of these fringing coral reefs could begin from the outer areas and move toward the interior. In fact, the consequences of long-term boring activity of the sponges were more obvious in the reef margins than in the central platforms, where a high percentage of complete detached live coral heads infected by boring sponges $(41.3 \%)$ was frequently found. Thus, in the reef margins the consequences of boring go far beyond the mere hollowing out of a few cavities, since by weakening the coral's attachment to the substrate, the sponges accelerate coral loss and deteriorate the reef edge structure. After they are dislodged, the fate of corals depends on the extent of injury suffered when turned over and the possibility of burial (e.g. Goreau \& Hartman 1963). But in some cases the effect on the corals may be positive and support asexual propagation (Tunnicliffe 1979). In the Caribbean, it was noted that borers basally broke $87 \%$ of the live colonies of Acropora cervicornis, mainly by Cliona aprica, aiding to the asexual propagation of the coral (Tunnicliffe 1979). We do not know if the same positive effect occurs in Pocillopora damicornis branches dislodged from the reef matrix; however, the loss of reef framework in LE during recent years seems to suggest the opposite (Lirman et al. 2001).

Boring sponge abundances have previously been linked to disturbance events on reefs (e.g. Rose \& Risk 1985). The present study yielded values (up to 50\%) that more closely match boring sponge occurrences previously found on impacted or stressed reefs (Holmes 2000, Macdonald \& Perry 2003). In contrast, in well-conserved Caribbean reefs much lower values are reported than those for non-impacted reefs, for example: from 0.8 to $23 \%$ in Barbados (MacGeachy 1977), from 13 to $14 \%$ in Belize (Highsmith et al. 1983), from 7.7 to $19.4 \%$ in Colombia (López-Victoria \& Zea 2004) and 14.2\% in Cuba (Buznego \& Alcolado 1987). It seems that the infestation frequency of boring sponges is always lower than $23 \%$ on Caribbean coral reefs considered healthy (MacGeachy 1977, Highsmith et al. 1983, Buznego \& Alcolado 1987, López-Victoria \& Zea 2004). Thus, it can be argued that the present 2 
reefs are, or were, severely disturbed. However, environmental data obtained for LE and SA were incongruent with organic enrichment or eutrophication, factors that are considered highly influential in the increase of boring sponge abundances (Rose \& Risk 1985, Holmes 2000, Macdonald \& Perry 2003).

Although in general we could consider both reefs unpolluted, important differences between the 2 reefs exist. SA presents a more compact and homogeneous structure (Leyte-Morales 2001), but LE, with the highest frequency of infestation by boring sponges, is currently subjected to intensive tourist activities and unregulated fishing. Moreover, incidents of natural perturbations, such as storms and hurricanes that have had catastrophic effects, have resulted in the deterioration of LE, weakening its structure and causing the detachment of massive corals and big blocks (ca. $1 \mathrm{~m}^{3}$ ) (Lirman et al. 2001). Losses of coral cover in LE exacerbated the numerous depressions that cross and interrupt its framework, making it more heterogeneous. An increase in heterogeneity and the area of exposed carbonate surface on the central platform may have promoted bioeroders and may in part explain the differences found between LE and SA, with sponge infestation rates of 41.3 and $11.1 \%$, respectively.

A healthy reef exists in a state of dynamic balance between growth and the coupled effects of bioerosion and wave shock. In healthy non-impacted reefs the rates of reef growth and destruction are generally in balance (Hutchings 1986), but in impacted reefs, the rates of bioerosion greatly exceed the rates of growth (Kiene 1988, Peyrot-Clausade et al. 1995). Thus, the combined effects of natural phenomena and constant anthropogenic impact on LE promote fragmentation, breakage and transportation of big coral colonies, which considerably decrease the coverage of live coral tissue and increase its susceptibility to destruction during hurricanes and storms (Glynn et al. 1998, Lirman et al. 2001). These events lead to increasing amounts of exposed carbonate substrate available, favouring infestation and abundance from boring sponges and other micro- and macroborers, thereby accelerating the natural process of reef degradation.

Acknowledgements. The authors acknowledge the following sources of funding: CONACYT SEP-2003-C02-42550, CONABIO FB666/S019/99, CONABIO FB789/AA004/02 and CONABIO DJ007/26, and the permission conferred for the collection of the samples on coral reef of Huatulco issued by the Parque Nacional Bahías de Huatulco. We thank A. Torres for her hospitality and for access to facilities of the laboratory in Oaxaca. L. F. Vasquez, L. K. López, D. F. Borrego and C. Vega assisted during chemical analyses, H. Hernandez helped with the photographic images during the sampling, and C. Ramírez (ICML-Mazatlán) provided some of the literature.

\section{LITERATURE CITED}

Buznego M, Alcolado PM (1987) Frecuencia de ataques de esponjas perforadoras sobre algunos corales escleractíneos y otros sustratos marinos en Cuba. Rep Invest Inst Oceanol Acad Cienc Cuba 59:1-18

Carballo JL, Cruz JA, Gómez P (2004) Taxonomy and description of clionaid sponges (Hadromerida Clionaidae) from the Pacific Ocean of Mexico. Zool J Linn Soc 141:353-387

Carballo JL, Hepburn L, Nava HH, Cruz-Barraza JA, Bautista-Guerrero E (2007) Coral reefs boring Aka species (Porifera: Phloeodictyidae) from Mexico with description of Aka cryptica nov. sp. J Mar Biol Assoc UK 87:1477-1484

Carriquiry JD, Reyes-Bonilla H (1997) Estructura de la comunidad y distribución geográfica de los arrecifes coralinos de Nayarit, Pacífico de México. Cienc Mar 23:227-248

Cortés J, Macintyre IG, Glynn PW (1994) Holocene growth history of an eastern Pacific fringing reef, Punta Islotes, Costa Rica. Coral Reefs 13:65-73

Glynn PW, Ault JS (2000) A biogeographic analysis and review of the far eastern Pacific coral reef region. Coral Reefs 19:1-23

Glynn PW, Colgan MW (1992) Sporadic disturbances in fluctuating coral reef environments: El Niño and coral reef development in the eastern Pacific. Am Zool 32:707-718

Glynn PW, Leyte-Morales GE (1997) Coral reefs of Huatulco, West Mexico: reef development in upwelling Gulf of Tehuantepec. Rev Biol Trop 45:1033-1047

Glynn PW, Lirman D, Baker AC, Leyte-Morales GE (1998) First documented hurricane strikes on eastern Pacific coral reefs reveal only slight damage. Coral Reefs 17:368

Goreau TF, Hartman WD (1963) Boring sponges as controlling factors in the formation and maintenance of reefs. In: Soggnaes RF (ed) Mechanisms of hard tissue destruction. Am Assoc Adv Sci Publ 75:25-54

Highsmith RC, Lueptow RL, Schönberg SC (1983) Growth and bioerosion of three massive corals on the Belize barrier reef. Mar Ecol Prog Ser 13:261-271

Holm-Hansen O (1978) Chlorophyll a determination: improvements in methodology. Scripps Institution of Oceanography, University of California, La Jolla, CA

Holmes KE (2000) Effects of eutrophication on bioeroding sponge communities with the description of new West Indian sponges, Cliona spp. (Porifera: Hadromerida: Clionidae). Invertebr Biol 119:125-138

Hutchings PA (1986) Biological destruction of the coral reefs. A review. Coral Reefs 4:239-252

Kiene W (1988) A model of bioerosion on the Great Barrier Reef. Proc 6th Int Coral Reef Symp 3:449-454

Kiene WE, Hutchings PA (1994) Bioerosion experiments at Lizard Island, Great Barrier Reef. Coral Reefs 13:91-98

Leyte-Morales GE (2001) Estructura de la comunidad de corales y características geomorfológicas de los arrecifes coralinos de Bahías de Huatulco, Oaxaca, México. MSc Thesis, Universidad del Mar, Puerto Ángel, Oaxaca

Lirman D, Glynn PW, Baker AC, Leyte-Morales GE (2001) Combined effects of three sequential storms on Huatulco coral reef tract, Mexico. Bull Mar Sci 69:267-278

Londoño-Cruz E, Cantera JR, Toro-Farmer G, Orozco C (2003) Internal bioerosion by macroborers in Pocillopora spp. in the tropical eastern Pacific. Mar Ecol Prog Ser 265:289-295

López-Victoria M, Zea S (2004) Storm-mediated coral colonization by an excavating Caribbean sponge. Clim Res 26: 251-256

Macdonald IA, Perry CT (2003) Biological degradation of coral framework in a turbid lagoon environment, Discovery Bay, north Jamaica. Coral Reefs 22:523-535 
MacGeachy JK (1977) Factors controlling sponge boring in Barbados reef corals. Proc 3rd Int Coral Reef Symp 2: 477-483

Naranjo SA, Carballo JL, García-Gómez JC (1996) Effects of environmental stress on ascidian populations in Algeciras Bay (Southern Spain): possible marine bioindicators. Mar Ecol Prog Ser 144:119-131

Perry CT (1998) Macroborers within coral framework at Discovery Bay, north Jamaica: species distribution and abundance, and effects on coral preservation. Coral Reefs 17: 277-287

Peyrot-Clausade M, Hutchings P, Richard G (1992) Temporal variation of macroborers in massive Porites lobata on Moorea, French Polynesia. Coral Reefs 11:161-166

Peyrot-Clausade M, Le Campion-Alsumard T, Hutchings $P$, Le Campion J, Payri C, Fontaine MF (1995) Initial bioerosion and bioaccretion on experimental substrates in high island and atoll lagoons (French Polynesia). Oceanol Acta 18:531-541

Reyes-Bonilla H (2003) Coral reefs of the Pacific coast of México. In: Cortés J (ed) Latin American coral reefs. Elsevier, Amsterdam, p 331-349

Reyes-Bonilla H, Carriquiry JD, Leyte-Morales GE, CupulMagaña AL (2002) Effects of the El Niño-southern oscillation and the anti-El Niño event (1997-1999) on coral reefs of the western coast of Mexico. Coral Reefs 21: 368-372

Richmond RH (1993) Coral reef: present problems and future concerns resulting from anthropogenic disturbance. Am Zool 33:524-536

Rose CS, Risk JM (1985) Increase in Cliona delitrix infestation of Montastrea cavernosa heads on an organically polluted

Editorial responsibility: Roger Hughes, Bangor, UK portion of the Grand Cayman fringing reef. PSZN I: Mar Ecol 6:345-363

Rützler K (1971) Bredin-Archbold-Smithsonian survey of Dominica: burrowing sponges, genus Siphonodictyon Bergquist, from the Caribbean. Smithson Contrib Zool 77: $1-37$

Rützler K (1974) The burrowing sponges of Bermuda. Smithson Contrib Zool 165:1-33

Schönberg CHL (2001a) Small-scale distribution of Great Barrier Reef bioeroding sponges in shallow water. Ophelia 55:39-54

Schönberg CHL (2001b) Estimating the extent of endolithic tissue of a Great Barrier Reef clionid sponge. Senckenbergiana Maritima 31:29-39

Schönberg CHL, Wilkinson CR (2001) Induced colonization of corals by a clionid bioeroding sponge. Coral Reefs 20: 69-76

Stoddart DR (1973) Coral reefs of the Indian Ocean. In: Jones OA, Endean R (eds) Biology and geology of coral reefs. Academic Press, New York, p 51-92

Tunnicliffe V (1979) The role of boring sponges in coral fracture. In: Lévi C, Boury-Esnault $\mathrm{N}$ (eds) Colloques Internationaux du CNRS 291. Biologie des spongiaires. Paris, p 309-315

Wild C, Woyt H, Huettel M (2005) Influence of coral mucus on nutrient fluxes in carbonate sands. Mar Ecol Prog Ser 287: $87-98$

Zar JH (1984) Biostatistical analysis, 2nd edn. Prentice Hall, Englewood Cliffs, NJ, p 718

Zubia M, Peyrot-Clausade M (2001) Internal bioerosion of Acropora formosa in Reunion (Indian Ocean): microborer and macroborer activities. Oceanol Acta 24:251-262

Submitted: May 15, 2007; Accepted: October 4, 2007

Proofs received from author(s): February 22, 2008 